\title{
Response to "optic nerve sheath diameter guided detection of sepsis associated encephalopathy"
}

\author{
Ziyue Yang and Tongwen Sun * (1)
}

\section{To the Editor:}

Dear Professor Suresh,

Thanks for your interest in our research.

First, regarding the blind method, being uninformed of the clinical diagnoses of patients is unavailing, since clues will still be found in patients' clinical manifestations (soberness/delirium/irritability/sleepiness/coma). Therefore, two trained physicians in intensive ultrasound were selected for joint measurement. After each measurement, the images were stored on the ultrasound machine, on which the optic nerve sheath diameter (ONSD) was measured. This can minimize the influence of subjective factors on the measurement. This is perceived as an appropriate blind method [1].

Second, the sepsis patients included in the research were aged between 18 and 93. However, in our experiment, we did not encounter patients with split or trabecular optic nerve sheaths, nor difficulties in the measurement due to skeletal problems, though these did appear in clinical work. Therefore, more comprehensive consideration is necessary during research on the largesized sample. Any of these situations will be excluded if it has a big impact on the result.

Third, no significant difference was identified in serum albumin concentration among patients in different

This comment refers to the article available online at https://doi.org/10.1186/ s13054-020-03232-7.

${ }^{*}$ Correspondence: suntongwen@163.com

General ICU, The First Affiliated Hospital of Zhengzhou University, Henan

Key Laboratory of Critical Care Medicine, Zhengzhou Key Laboratory

of Sepsis, Zhengzhou 450052, China groups (sepsis group, sepsis-associated encephalopathy group, and sepsis-associated encephalopathy recovery group) (28.9 [25.5,31.05], 30.5 [27.6,32.2], 34.75 [29.7,36]), especially between the sepsis group and the sepsis-associated encephalopathy group. Therefore, a small correlation between albumin and ONSD cannot prove the role of albumin in dominating intracranial pressure/onsd. Furthermore, intracranial pressure may also be affected by factors such as albumin, blood sugar, bedside angle, ventilator parameters, end-tidal carbon dioxide concentration, blood pressure, respiratory rate, and state of consciousness [2, 3]. The results will be further revealed in follow-up research.

Finally, thanks again for your letter.

Acknowledgements

None.

\section{Authors' contributions}

ZYY designed the study. TWS edited the English text of this manuscript. All authors participated in drafting and reviewing the manuscript. Both authors read and approved the final manuscript.

\section{Funding}

This study was supported by the Scientific and Technological Innovation Leaders in Central Plains (Grant No. 194200510017), Provincial Ministry CoConstruction Project from the Medical Scientific and Technological Research Program of Henan Province (Grant No. SBGJ2018020), the "51282" Project Leaders of Scientific and Technological Innovative Talents from Health and Family Planning Commission in Henan Province (2016-32), and Science and Technology People-Benefit Project of Zheng Zhou (2019KJHM0001).

\section{Availability of data and materials}

All data generated or analyzed during this study are included in this published article and its supplementary information files. original author(s) and the source, provide a link to the Creative Commons licence, and indicate if changes were made. The images or other third party material in this article are included in the article's Creative Commons licence, unless indicated otherwise in a credit line to the material. If material is not included in the article's Creative Commons licence and your intended use is not permitted by statutory regulation or exceeds the permitted use, you will need to obtain permission directly from the copyright holder. To view a copy of this licence, visit http://creativecommons.org/licenses/by/4.0/. The Creative Commons Public Domain Dedication waiver (http://creativeco mmons.org/publicdomain/zero/1.0/) applies to the data made available in this article, unless otherwise stated in a credit line to the data. 


\section{Ethics approval and consent to participate}

This study has been approved by the Scientific Research and Clinical Trial Ethics Committee of the First Affiliated Hospital of Zhengzhou University (Code 2020-KY-035).

\section{Consent for publication}

Not applicable.

\section{Competing interests}

The authors declare that they have no competing interests.

Received: 5 August 2020 Accepted: 18 November 2020

Published online: 07 December 2020

\section{References}

1. Yang Z, Qin C, Zhang S, Liu S, Sun T. Bedside ultrasound measurement of optic nerve sheath diameter in patients with sepsis: a prospective observational study. Critical care (London, England). 2020;24(1):235.
2. Dubourg J, Javouhey E, Geeraerts T, Messerer M, Kassai B. Ultrasonography of optic nerve sheath diameter for detection of raised intracranial pressure: a systematic review and meta-analysis. Intensive Care Med. 2011;37(7):1059-68.

3. Robba C, Santori G, Czosnyka M, Corradi F, Bragazzi N, Padayachy L, Taccone FS, Citerio G. Optic nerve sheath diameter measured sonographically as non-invasive estimator of intracranial pressure: a systematic review and meta-analysis. Intensive Care Med. 2018;44(8):1284-94.

\section{Publisher's Note}

Springer Nature remains neutral with regard to jurisdictional claims in published maps and institutional affiliations.
Ready to submit your research? Choose BMC and benefit from:

- fast, convenient online submission

- thorough peer review by experienced researchers in your field

- rapid publication on acceptance

- support for research data, including large and complex data types

- gold Open Access which fosters wider collaboration and increased citations

- maximum visibility for your research: over 100M website views per year

At BMC, research is always in progress.

Learn more biomedcentral.com/submissions 